Wheat Seed for Afghanistan

Prepared For Office of the AlD

Representative, Islamabad

Honer H. Hepworth

October 27,1988 


\section{TABLE OF CONTENTS}

ACKNOWLEDGEHENTS (Wheat Seed for Afghanistan)

SUHHARY 2

Varietias 2

Seed Transport and Distribution 3

INTRODUCTION/BACKGROUND 5

Seed Grains 6

Anount of Seed Needed 8

$\begin{array}{ll}\text { Spring Wheats } & 10\end{array}$

Winter Wheats 11

$\begin{array}{lr}\text { Seed Procureaent } & 12\end{array}$

Seed Treatment 14

Certain Disadvantages Inherent in Seed Treatents 15

Packaging Seed 16

Seed Testing 17

SEED TRANSPORT DISTRIBUTION

ACTIONS REQUIRED

APPENDICES

1. Seed Conpanies 23

2. Justification for Wheat Seed Money 29

3. References 34

4. Persons Contacted 35

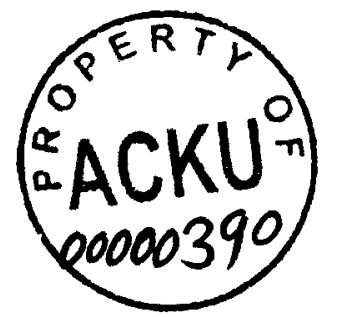




\title{
WHEAT SEED FOR AFGHANISTAN
}

\section{By: Hower H. Hepmorth (October 1988)}

\begin{abstract}
This report was prepared for O/AID/REP, Islamabad, Pakistan to address two ajor issues; first identification of suitable wheat varieties which can be recomanded for use by faraers returning to or currently in Afghanistan and second, developent of aechanisias/strategies for production/procureaent and distribution of the seed of the identified/recomended wheat varieties to those farners.
\end{abstract}

The author has had personal discussions and interviews with numerous experts, scientists and colleagues and has read numerous reports and papers related to the issues stated above. These are enuerated in Appendices to this report. Sincere appreciation is hereby expressed to all who assisted in any way in the preparation of this report. 


\section{SUKKARY}

A asjor assistance effort is sorely needed to rehabilitate Afghan agriculture. The prolonged war has done great dasage to physical resources, roads, irrigation facilities etc. In addition seed for crops has degenerated or been destroyed or lost. Wheat is the most important food crop in Afghanistan. Providing substantial quantities of ieproved wheat seen is an inportant component of any rehabilitation effort. It is critical that contracts for seed wheat be neqotiated within 10 to 15 days. If no contracts are made the seed companies will in turn not be able to contract with their seed producing farmers and quality seed will not be available. Wheat nust be seeded by Novenber 20 to produce the seeds for next year.

Varieties: Two varieties of wheat have been identified and reconsended for the spring wheat seeded areas lover $80 \mathrm{z}$ of the wheat area).

1 - PAK 81 lalso known as Veery 6, Cathay and Seri 82) is a high yielding disease resistant variety. Certified seed of this variety can be procured in Pakistan and other countries. It is suggested that 4500 tons of this seed be sent to Afghanistan in 1989. 
2 - Firsabak 85 is a newly released highly yielding, diseased esistant variety. Only rather liaited quantities of the variety are now available but it should be increased as rapidly as possible. Five hundred $(500)$ of this seed can be ready for Afghanistan in 1989.

B - Winter Wheat varieties are of lower priority. Soae winter varieties previously grown in Afghanistan can be reconaended if seed is available there. If not seed can be found in Turkey or Eastern Europe. These varieties are Besotaya, Kavkaz, Bolal and Roussulka They are not available in Pakistan.

Procuring Seed: Several sources are available in Pakistan; Cargill Pakistan Seed Lisited, Punjab Seed Corporation and Pioneer Seed International all in Lahore. (See Appendix for details)

\section{Seed Transport and Distribution}

1. Decision re: seed treatient and packaging etc. sust be negotiated with suppliers.

2. Seed quality specifications nust be agreed upon with the supplies at the tise of contracting. 
3. Several possible options res transporting and distribution seeds should be investigated.

a) According to the Arestrong/Rude report private trucking companies are able to transport the seed at least to ajor points in Afghanistan.

b) Vita way be a useful agent assisting with transport and distribution of seed, especially if they have 10 established centers in Afghanistan.

c) The proposal advanced by the Fertilizer Tean report (Section IV pages 29-32 and section $V$ pages 33-38) is the nost detailed and plausible system proposed. They also, clearly state the importance of closely coordinated sovenents of seed and fertilizer.

d) Any scenario considered requires a cadre of trained, responsible Afghans to supervise and carry on a distribution schene. 
The situation in Afghanistan which resulted in the eaigration of ailions of refugees ainly into Pakistan and Iran as well as to other countries has been in progress for several years. Hajor disruptions have, no doubt, taken place in Afghanistan's agricultural sector Nuch physical danage has been done to the agricultural resource and support base e.g. ruined irrigation systeas, damaged roads, work animals killed, etc. At best, before the war, the research necessary to develop better seeds, and inproved manageaent practices, was woving ahead with nodest speed in Afghanistan. In addition, the developaent and iapleaentation of the infrustructure to make available necessary resources for increasing production e. 9 . better ioplementation and mechanization, fertilizers, etc. faced many obstacles. Nevertheless, it appears that through diligence and hard work the cereal grain production systea in Afghanistan was essentially keeping pace with the increasing population until the onset of the current situation in 1978.

Now with in-country production reduced by an estiated 50 percent and 3 to 5 aillion refugess reared from their homes and their fares obviously a very serious situation is at hand. Under the recent accords, but of course very auch contingent upon in-country socio-political developments, it appears that a repatriation movenent ay begin in the not too distant future. Clearly if the aillions of 
refugees are to return to their hoaelands and begin to rebuild their agrarian existence, ajor assistance efforts will be in order. The earlier it becones possible for the refugees to produce food and other necessities for thenselves the better for thee and for the eany agencies who have so valiantly provided assistance of various sorts for the past eany years. The wisdon of the old Chinese proverb coses to aind. If you give a an a fish you have fed hie for a days if you teach hie how to fish you have fed hie for his lifetine/.."

No doubt there will be great deaand and necessity for all sorts of assistance and resources. This will, depending upon the rate of return of the refugee population, probably involve very sizable food grain ieports to sustain the population while they are rebuilding their agriculture base. It is of great ieportance to bear in and the critical need to get in-country agricultural food production underway as rapidly as possible. At best several oonths are required for production of cereal grain crops and only one crop each year is produced in sost of Afghanistan. Hence, this effort should receive highest priority.

\section{Seed Grains}

Bread wheat is by far the oost inportant cereal crop produced in Afghanistan. A recent survey shows that in 1978, 2,345,000 hectares 
were devoted to wheat production conpared to 400,000 for aaize, 310,000 for barley and 210,000 for rice. The flat bread (MAN) is a staple in the Afghan diet. These figures anply justify the priority placed on getting wheat production back in progress as soon as possible. There is general agreenent that in-country seed production systees have broken down and are now disbanded. In addition, while sose agricultural production has continued, supplies of suitable seed have been diluted or exhausted and no satisfactory or inproved seeds have becone available. Interestingly, a very linited anount of research has continued and some data concerning selection and perforance of new wheat varieties has filtered out to international cooperating agencies (CIMHYT, Oregon State University, Nebraska University and probably others). Fortunately, for any years several agencies/organizations have been carrying on cooperative research prograns on a morld wide basis. Thus, gere plase of inproved varieties of cereal grains receives world wide distribution and testing under very diverse conditions of clisates, environeent, biological stresses and nanagenent factors. The result of this world wide cooperative progran has been the breeding and selection of varieties which show very broad adaptability to environeent and eanageent as well as resistance to most diseases. Disease resistance nay function within oore linited geographic areas. For exaeple a variety eay shon resistance to leaf rust but not to stripe rust and thus be reconoended only for areas where stripe rust is not 
a problee. Discussions with eany recognized wheat experts in Pakistan and froe other institutions (e.g. CIMMYT, OSU, USDA, ARS) who are very faeiliar with Pakistan and to soes degree, Afghanistan, resulted in coeplete accord on wheat varieties to recoenend for Afghanistan. A review of available research results substantiated the opinion of the experts (as expected). Based upon the discussions and research reports l believe optieisa and confidence are in order as regards varietal reconaendations.

Afghanistan does contain rather diverse bio/environeental areas which should be considered in the variety selecting process. Such factors as teeperatures, diseases encountered, length of season, tiee of planting etc, are ieportant. Over long periods of tioe, well supported research prograes can fine tune the variety developeent and selection process to a high degree. Afghanistan currently has neither the tive nor the research capability for this process. Fortunately, an indicated earlier researchers in Afghanistan, Pakistan and other areas (CIMMYT/Mexicol have been able to develop and test ieproved, high yielding, disease resistant varieties of wheat which can be reconeended for use in eost of Afghanistan.

\section{Apount of Seed Needed}

laportation of enough seed to eeet the evident needs of Afghanistan 
appears iepractical as well as nearly iepossible. Afghanistan produces roughly 2,400,000 hectares of wheat each year. This requires a einieue of 240,000 tons of seed (at $100 \mathrm{kgs} / \mathrm{hectare}$ ) but very likely euch oore because of the high seed rates required. Bone reports quote seed rates as high as $200 \mathrm{~kg} / \mathrm{hectare.} \mathrm{Of} \mathrm{course} \mathrm{only} \mathrm{a}$ seall part of the fareers use "new" seed each vear. Host of the seed is held over by the fareer froe his previous years crop. No doubt eost wheat varieties are used wuch longer that the 5-7 years which is the average of optious lifetioe of a variety. Clearly the ieportation of 5000 tons of ieported seed in 1989 mould be only a sall beginning covering at nost 50,000 hectares once the ieportation systee is functioning it is suggested that 15 to 20 thousands tons be ieported in 1990 and probably 30 thousand tons in 1991 for a total of 50,000 tons of iaported wheat seed. Assuaing that this wheat produces average or above yield this mould eean 50,000 tons in $1990,200,000$ tons in 1991 and 300,000 tons in 1992. This is total production. Obviously not all of the increase will be used for seed. Huch of it will be consuned for food. However, eost seed in Afghanistan ooves froe fareer to fareer so within a feu years the new seed could be quite widely spread. If sone ecchanise can be put into place to purchase and redistribute the inproved seed it would be spread euch nore rapidly. This would probably require replacing the ieproved seed with food wheat to neet the fareer's faeily requireaents Every ton of seed ioported aeans at least 10 
tons of food wheat, a far eore efficient eethod than ioporting wheat or flour.

\section{Sering Wheats}

1. For the lower regions of the country where severe, killing frost are unlikely the variety PAK 81 lalso known as Veery 6 , Seri 82 and Cathay) can be reconended. This variety is widely grown in Pakistan, Spain, Mexico and other areas. It has high yield potential bet is hardy and does well under eore restrictive growing conditions. It is resistant to stripe rust, the oajor cereal disease in Afghanistan. This variety is a product of the winter and spring wheat crossing prograns and does contain oore cold tolerance than ay be found in the pure spring wheats. It has been tested at elevation above 2500 eeters. Due to its extensive production, larger quantities of seed could be avajlable for distribution into Afghanistan.

2. Pirsabak 85 is a nemly released variety selected by the Cereal Research Institute at Pirsabak Station, Nowshera NafP. It is a selection fron PAK 81 but has shown higher yield potential and better disease resistance. Nuch of the wheat area in Afghanistan is eovironeentally sioilar to that in NHFP so this variety should do even better than pak 81. It should be noted that supplies of this variety will be lieited as it is only in the late seed oultiplication 
stage. But it should be increased and distributed as rapidly as possible.

3. The cereal breeding progran at CCRI Pirsabak has several other proeising new lines under test at their station. As soon as possible soee of these should be, increased and distributed for testing and release in Afghanistan. This will reduce the potential for problens such as a disease epideeic, which can develop when too wuch area is covered by a single cultivar.

\section{Winter Wheats}

I have been unable to find information and data concerning selection and testing of any new varieties of winter wheats suitable Afghanistan. However, it appears that several of the varieties which have been produced in Afghanistan are still maintaining acceptable disease resistance and production levels. Seed of these varieties should be made available to the farmers as it is believed that in-country seed has been diluted with old land race varieties or 1ost. Winter wheats cover less than $20 z$ of the cropped area. Varieties which are known to do well in the winter wheat growing areas are Besostaya, Bolal, Roussulka, Kavkaz. Seed of these varieties could be obtained in eastern Europe or Turkey. 
Seed Procurenent

Recoenending varieties appears to be the sieplest part of this proposed effort. The procureent, handling and distribution of the seed is obviously ore conplex and subject to eany variables. Packaging, seed testing, seed treateent, shipping and final disribution nust be all considered and careful preparations planned and executed.

1. Procureeent:

Several sources of seed ay be considered. Obviously, if quality seed can be obtained close to the distribution areas shipping and handling probleas and cost can be ainiaized. Possible seed sources for Pak 81 are Pakistan, Spain and Mexiso. Both Mexico and Spain have seed companies with experience and capability in seed procurement and shipping. Punjab Seed Corporation in Pakistan also has been producing, and earketing seeds for several years. This is a para-statal organization and has dealt eainly with contract fareers on land owned by the PSC for production of seed. Recently two private sector seed enterprises of note have been established in Pakistan: Cargill Pakistan Seed Ltd, and Pioneer Seeds Ltd., both located in Lahore. To ay knowledge, there is no well organized seed 
production and narketing entity in NWFP, however the two private conpanies noted are operating there and are developing relations with the research organizations in MUFP. Punjab Seed Corporation has traditionally produced and processed only the anounts of seed anticipated to neet arket requirements of their areas. However, following the recent disaster in Bangladesh sose 2,000 tons of wheat seed was allocated for shipeent to Bangladesh. In order for PSC to eeet the probable increased deand for the next year as well as produce the additional tonnage required for shipent to Afghanistan PSC mould have to be authorized, in the very near future, to increase its contracting base with seed producing fareers and to eake suitable arrangeeents for the special seed packing required. The widespread flood which occurred during the past two meeks has, no doubt, caused the loss or spoilage of a great acount of fareer held seed. The effects of this tragedy upon PSC and the agriculture of the region are not known at present but this should be carefully investigated as part of any contracting procedure with PSC.

While the seed production/arketing organizational capacity in the Mufp ay be weak it is well known that in Mardan area there are any successful, progressive fare operations. This could well be the sost advantageous area for production of seed for Afghanistan. Pak 81 is approved and produced in the area. Pirsabak 85 , the new variety, was developed and released for that area. The area is euch closer to 
Afghanistan and the socio-political raaifications involving NWFP in the Afghan assistnce effort deserve strong consideration. Prossibly one or ore of the conaercial seed companies could be utilized in the coatracting/production/processing and packaging operation. Again, propt action will be necessary as seeding tiee is near. Soue involvenent of conercial interests is already evident in that one coepany has arranged for a sizeable quantity of the available basic seed of Pirsabak 85 for increase and sale in the seed arket.

\section{Seed Treatment:}

Certain advantages are obtained fros cheaically treating crop seeds before or at seeding tine..

1. Seed is protected against insects and/or against invasion by plant diseases or haraful soil organisas. Thus seed geraination and eargence are enhanced.,

2. A debatable but potential advantage in these circuestances is that treated seed cannot/will not be diverted in to food channels and eaten because of the toxic nature of the seed treateents. This assuees an awareness on the part of the Afghan faraer that the seed is treated and toxic. 


\section{Certain Disadvantages Inherent in Seed Treataents}

a. Carelessness or error in application of seed treateent can reduce seed viability and geraination. This is particularly true when seed is treated a long tiae before seeding.

b. Particularly with uneducated, inexperienced fara populations, the risk of treated seed entering food channels (or aninal feed) is higher. Seeds can be treated with dyes so that they are colored and this should alert potential consuners to the fact that the seed is not for food user. This obviously entails an educational effort and assunes that such practices as washing the seed to renove the dye would seldon occur..

c. Depending upon several factors the loss froe using untreated seed may vary considerably - froe essentially no loss to severe losses.

Under hot, huaid conditions which favor insects and diseases seed storage is difficult and losses can be high. Seed treateents, and funigation, etc. are very inportant. However, under rather dry, lon hueidity conditions, wheat seed is a rather durable conodity and risk of dasage is lower, even without chenical application. Seed stored in the Punjab through a monsoon season is under much greater risk than seed stored in Kabul, Afghanistan. 


\section{Packaging Seed:}

Traditionally, oost wheat seed in Pakistan has been arketed/distributed in jute (gunny) bags of 90 kilogras (198 (bs) asounts. While this ceans less bags to load, unload and handle it also results in great difficulty and very strenuous labor for the handlers and considerable spillage and waste due to torn and dropped bags. Jute bags are subject to easy penetration by insects and are not waterproof. It would appear that other packaging sethods say offer several advantages.

1. The size/weight of the package should be reduced. Maxious size should not exceed $50 \mathrm{kgs}$.

2. A nini-pack progran should be considered in which sealler packages of 5,10 or/and 20 kilograns should make up a portion of the seed shipsent. This is for two reasons. First, there is real serit in getting the seed into the hands of a larger number of farsers, rather than giving fewer faraers larger anounts of seed. This approach should be appealing because ore fareers feel they are included in the progran. Second, the seed will be used over a auch larger geographic base even though in sealler plantings.

3. The transport and handling of soaller packages will be euch easier for saller landowners to eanage with a donkey or on foot. 


\section{Larger farmers or those nearer to distribution centers can probably use $50 \mathrm{~kg}$. packages.}

In the Lahore area where it is anticipated that ast seed from Pakisan will originate, both jute and laainated (reinforced) polypropylene bags are available. The nost secure packaging would be with a polypropylene liner inside a jute bag outer cover. This would add slightly to the total cost but is a arginal increase and will neasurably protect the big investment - the seed itself.

\section{Seed Testing -}

Comon practice in the seed industry is to establish quality standards which are to be aet for the seed to be accepted by the purchasers. Genetic purity, germination/viability percentage, anount of inhert atter and amount of weed seed are comon seed quality components. When a seed contract/order is ade these factors aust be specified and quantified. During the crop season regular field inspection must be scheduled and carried out to verify genetic character and purity.

Comonly accepted standards for wheat seed ares

Genetic purity 997 No living insect 


Germination
Inert atter
weed seed

At harvest time cleaning, treating and germination testing are completed prior to acceptance and of the seed lot by the purchases.

Another geraination test way be run at seeding tiae to insure that proper seed rates are reconaended.

Seed Transport and Djstribution

It appears that transporting the seed from the point of delivery (Lahore, Kanewal or Mardan) to ajor distribution points in Afghanistan can be arranged with reasonable confidence in tisely delivery. Several systens of seed distribution can be utilized.

A. The report of Arastrong and Rude indicates that a very viable private transportation sector exists and could be utilized.

B. VITA has successfully noved substantial tonnages of conodities into Afghanistan and is establishing a network of distribution information centers. Likley VITA could play a useful role. 
c. The report of the Cheoonics fertilizer teas contains the cost extensive inforation regarding transport and distribution of capabilities. It, very correctly, stresses the ioportation and use of seed and fertilizer as being linked and outally ioportant. The report (Section IV pages 29-32 and Section V) proposes a echanise for organizing and executing the transport and distribution of seed and fertilizer. It also includes price estimates. According to the calendar of events and actions proposed, the seed could be lifted and -oved to distribution points in Afghanistan before the systee is required to nove the fertilizer. There appears to be great eerit in linking the seed and fertilizer cosponents as proposed.

Hinipacks: It a sizeable proportion of the refugees return to Afghanistan as they left i.e. trekking over land with their anieals and belongings, seed eust be available at ajor border crossing areas. There, each farner or faoily group could be given 10 or 20 kgs or sore of seed to carry with thes.

B. Depending upon available transportation seed can be soved fros ajor centers, (Kabul, Kandahar, etc.) to outlying distribution centers. There, either the village leaders or the Coseanders of the area can supervise further distribution. There is no doubt that the seed will be oore concentrated around distribution centers. However, 
it should spread quite quickly in the traditional anner - farmer to farner. As stated earlier a strong effort should be ade to achieve wide distribution. Probably involving the village leader and Area Comanders will help to encourage better distribution and decrease the posssibility for any group to "corner the narket" and deprive the majoity for profit reasons.

3. Reanants of the farmer seed production/distribution organization that previously existed ay be rehabilitated and serve a very useful role in seed distribution.

4. PUDs and NGOs can also be a very important resource in this effort.

5. Since a rather sizeable fertilizer procurement and distribution systen will also be in operation, it may be very advisable to link or conbine the two (seed/fertilizer) distribution systen when possible. This would assure that the farmer has both components of his production package when he is ready to seed.

6. It is inperative that a corp of supervisory people be trained and incorporated into this seed activity. They will help to assure that the systea functions and serves as auditors to discourage the inevitable pilferage and profiteering which will occur. 
This group will be expected and authorized to keep accurate records of the seed; anounts shipped, asounts received and final distribution. In addition, they will supervise pre-seeding seed geraination tests and advise farners regarding seed rates, fertilizer use, etc.

The experience of the Swedish Survey Group at Peshawar indicates that such a tea of Afghans can be selected and trained. Of course this tean will be in regular contact and work cooperatively with N60s, PVos, etc. While there should be broad based support for the seed prograe, it is also necessary that leadership and responsibility be clearly designated to prevent "too eany cooks froe spoiling the pie."

\section{ACTIONS REQUIRED}

Iteo 1. It is critical that contracts be negoziated with seed suppliers ASAP - with 10 to 15 days in order to get the seed production process into action. Wheat oust be seeded in Noveober for optioue production. Contracts for 4500 tons of Pak 81 and 500 tons of Pirsabak 85 sust be eade, as soon as possible.

Ites 2. A training progran for the teas of supervisors should be planned and prepared. The progran should be done during the winter 
so that the teas abers can participate in the seed inspection, procureaent, processing and packaging operations.

Itea 3. A record keeping systea should be ready and the tean abears faeiliar with it so that seed purchases, shipping records and distribution records are kept as accurately as possible.

Itee 4. Heetings should be planned to discuss and plan the operation with all participating agencies/organization i.e. PVos, No0s, other donors, etc.

Itea 5. Prelioinary discussions should be followed up with potential transportation resources and fira plans developed.

Itee 6. Cooperative plans should be ade with other resource suppliers i.e. fertilizer, farm impleants and anial power, etc. to assure that the required components cone together at the right tine.

Iteo 7. Plans should be ade for probable iaports of 15,000 tons of wheat seed in 1990 and 30000 tons in 1991. This should be considered in awarding a contract for Pirsabak 85 seed this year as that variety will have to be nultiplied from basic seed in 1990 and 1991. (see Append $(x 1)$. 
CARGILL PAKISTAN SEEDS (PUT) LTD.

\section{I6 Shadaan II Canal Bank}

Lahore, Pakistan

$413284-275062$

Mr. Jack Hessler

Country Manager

Dr. Abdul Rehaan

General Manager, Seeds

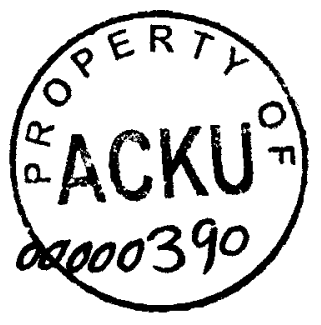

1. Cargill pak Seeds is now prepared to offer certified seeds of several crops which could be useful in Afghanistan; wheat, waize, sunflower, forage sorghue, safflower, rice and cotton. They have their own processing cleaning, treating and bagging plant with a present capacity to handle 3,500 tons. Of particular interest are wheat, aaize and forage sorghus.

2. Afghanis will need animal forages in sizeable quantities for their work animals, ailk and weat. Traditionally straw fron the wheat crop has been a eajor source of aniand forage. Of course straw is extreaely jow in food value and energy production. The forage 
sorghua (actually a sorghum/Sudan grass cross) is handy, drought resistant and will produce several cuttings per growing season thus yielding high tonnage per acre. This and the forage legunes should be standard forage crops.

3. Wheat is of ajor interest to Cargill pak seeds. They are prepared to provide seed of PAK 81 werranted to eest international standards for quality and packaged according to contract specifications. They anticipate a price for PAK 81 very near that quoted by PSC.

4. Seed for Pirsabak 85 is a different case to wit:

a) it has only recently been released so little seed is available. It is a selection fros PAK 81 but is shoming higher yields and better disease resistance. It is the variety that should be sent to Afghanistan as fast as seed can be oultiplied.

b) Contingent upon a fire contract in the very near future. Cargill Pak has requested 20 tons of the total of 64 tons of pre-basic seed available froe CCRI at Pirsabak. Cargill Pak could increase this seed and have a projected 500 tons for shipeent to Afghanistan in suaner 1989 for planting in the fall. 
Cargill pak would keep a quantity of this basic seed for altiplication in 1989-90 and would have a projected 3,000 tons for Afghanistan, for the 1990 seeding.

By 1991, following this procedure, Cargill Pak Seeds could have a projected 17500 tons for the final year of a three-year refuget repatriation progran.

\section{c) Key factorss}

(1) agreenent that Pirsabak 85 should be introduced to Afghanistan as a prise variety, as rapidly as possible.

(2) due to the soall seed base to begin with and that it will be eultiplied froe pre-basic, not basic or certified seed it will be core expensive, particularly in the first and second years. Contract negotiations would have to be done with Cargill pak Seeds to deteraine the total tioe frane and seed anounts. This would obviously affect the cost of Pirsabak 85 seed, but the price will be higher than for PAK 81.

5. As with Punjab seed Corp and Pioneer Seeds, Cargill Pak seed Ltd. is fire in their request that unless contracts are consunated within 10-15 days they cannot guarantee results. In that case seed 
available would be that from farmer fields - conercial wheat and would not have the regular inspections and guaranteed standards indicated for in certified seed.

99.92 genetically pace

esx aniaue gerapation

- living insects

earalent
22 maxisua ihert atter

5 - 10 gaxisun weed seed/kg. seed tested with vitorax or

and dyed

\section{FInIS}

Considering the projected high deands for seed fros PSC due to flood losses and denand fron other areas, it seems advisable to amard contracts for wheat seed to Cargill PaK Seeds. In spite of the obvious advantages of in-country procureaent if there appears to be uncertainty regarding ability to fulfill contract conditions, sources outside paxistan could be considered, i.e. Mexico or Spain for PAK 81 seed. There appears to be little risk in purchasing substantial quantities (i.e. 5000 tons or nore) of seed for 1989 delivery and Fall seeding. Even if the novenent of refugees back to Afghanistan is less than anticipated the farmers who have never left the country could certainly utillze the seed. This could help to build a better agricultural base for when the refugees do return. 
PUNJAB SEED CORPORATION

4-Lytton Road, Lahore Telephone: 211674

Dr. Abdul Haaid Chudry Managing Director

Mr. Huhasad Hassan Chudry Deputy Hanaging Director

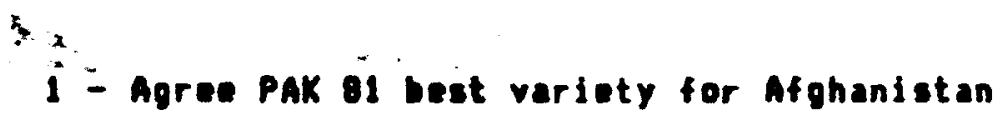

2 - PSC is wflling to contract ASAP for certified Pak 81 for end of June 89 delivery.

Seed to be: genetically pure germination winimu physical purity weeds, axinua no living insects treated for diseases (vitavox)
99.92

$85 x$

982

5-10 per pkg

3 - They will package according to contract specifications, ary be slight charge for sall packages and using polypropylyne with jute cover.

4 - Hust ake contract by end of Detober 89.

5 - Price quoted 5000 rupees/ton at Khanewal. 
PIONEER HI INTERNATIONAL INC.

92-AII

New Huslia Town, Lahore, Pak Tel 861-796

Mr. Ali Deairtas, MBA, Resident Representative

1 - Pioneer is not yet Involved in wheat seed earketing in pakistan.,

2 - Mr. Deeirtas, Turk, has experience with Pioneer Seeds in

Turkey and in supplying seed froe Turkey to Saudi Arabia.

3 - If winter wheat varieties are part of wheat seed for afghanistan

(i.e.) (Besostaya and Bolal) Pioneer could contract for that seed

(certified) froe Turkey, delivered to Pakistan.

4 - Nust ake contract within 15 days for guaranteed delivery.

5 - Pioneer can supply aize, sunflower, berseen, alfalfa, and sorghue/Sudan grass forage seed. 


$$
\begin{gathered}
\text { Justification for Wheat Seed Money } \\
\text { Dr. H. H. Hepmorth } \\
\text { Dr. Azan Bul }
\end{gathered}
$$

\section{Situation}

voriag the war Itififonentstan for the past 9 years soes oajor changes have occurred. A large part of the population (about one third) has left the country and are now living as refugees in Pakistan, Iran and other countries. Major dasage has been done in destroying towns, roads, irrigation systees, wining fields, etc. The labor supply is greatly reduced due to war injuries or enigration. Anisal power also is greatly reduced, either sold for survival or killed by mines, etc. Agriculture research has essentially stopped and seed production has also stopped. Total agricultural production has fallen an estimated 50 per cent.

With the signing of the Geneva accords, it now appears possible that actual wilitary conflit will cease within months. This will allow allions of refugees to return to their hoses and start rebuilding the agricultural sector. Agriculture involves about 85 per cent of the Afghan population.

In order to avoid serious food shortages and the attendant necessity 
for assive isportations of food, it seens logical that providing assistance in rehabilitating Afghan agriculture nould receive highest priority. Far better to help thee produce their om food than to just hand out supplies. Even so, food ieports will probably be required for a fen years.

\section{A Partial solution}

The eajor 1teo in the Afghan diet is nan, the flat, whole wheat bread preferred by Afghans. In fact, wheat is produced on well over 50 per cent of all the cropland seeded (2.34 villion hectares). Haize was seeded on 0.4 aillion hectares. The total per capita wheat utilization for Afghans is $200 \mathrm{~kg}$ per year, one of the highest in the world. Wheat provides nearly 80 per cent of the caloric intake for nost Afghans.

In order to assist Afghan fareers to increase wheat production three basic inputs are essential: water, seed and fertilizer. Other experts are developing assistance projects for repair and inprovenent of Afghan irrigation systees. A fertilizer tea (USAID) is preparing a report concerning fertilizer.

Host wheat in Afghanistan is planted in the fally Septeober, October, Noveber and harvested in the spring. Thus, it is now too late to 
ieport wheat seed into Afghanistan for seeding this crop year. However, in order to assure supplies of seed for the 1989 seeding, fire contracts with the seed conpanies oust be negotiated insediately. The seed companies sust in turn negotiate contracts with their seed producing farners. These farners will begin seeding their fields in a few days. The better faraers in Pakistan know that for every day thet wheat seeding is delayed beyond Movenber 10 they suffer a $40 \mathrm{~kg}$ per hectare yield decrease. Therefore, the contracting process aust be activated as soon as possible. Once the crop is planted and while it is growing, fire plans for seed processing (cleaning, treating, bagging, etc.) and transportation and distribution can be worked out and put in place.

At this tise, there is agreesent asong agricultural scientists and assistance agencies that substantial anounts of wheat should be eade ready, in Afghanistan, for the 1989 fall seeding. Wheat varieties have been identified that are high yielding, disease resistant and widely adapted to various environeental regiees. Inforeation and data fros a lieited nusber of research trials in Afghanistan proves these varieties do very well there. These varieties are produced here in Pakistan las well as other countries). Seed for Afghanistan can be ready for the 1989 seeding, assuning contracts can be put in place now. 
While assistance agencies (USAID, FAO, etc.) are all aware of the picture as outline above, no one has offered fire funding to get the necessary contracts award.

It is projected that, over a probable three year (or longer) period, the total wheat seed inportation eay approach 50 thousand tons (MT), depending upon how rapid repatriation of the refuges occurs. It is agreed that for the 1989 seeding 5000 MT should be purchased and in place in Afghanistan for the 1989 fall seeding.

Seed producing companies, e.g. Cargill Pakistan Seeds Ltd. in Lahore, are ready to proceed ineediately if contracts are nade. The seed coepanies request that 25 per cent of the contract value would be paid at the tioe the contract is signed with the balance to becone due when the seed is delivered, approxinately June 10 to july 1 , 1989. This contract binding fee would anount to not over $\$ 400,000$ U.S. This assunes a purchase price of U.S. $\$ 278$ per MT at the seed processing plant for the variety PAK 81 . For the other variety, Pirsabak 85, the price will initially be higher because this is a newly released variety and the seed oultiplication process begins further upstreas with pre-basic seed. As the anount Pirs 85 is increased sore of this variety should be included in the isportation effort, gradually relacing Pak 81. As Pirsabak 85 becoues availablo in larger quantities one would expect the seed price to decline and 
eventually reach the sane level as Pak 81 or other approved varieties.

Right now the critical issue is negotiating fire contracts with the seed conpanies so they in turn can ake agreeeents with their seed producing fareers.

Note 18 While this seed proposal is designed to assist returning refugees, there is no loss to be incurred should circuestances develop to retard the repatriation process. The fareers who are still in Afghanistan can also benefit greatly fron ieproved seed. 


\section{REFERENCES}

1. Results of the Twentieth ISHYN. 1984-85. CIMAYT, Hexico.

2. Results of the Twentyfirst 1SWYM. 1985-86. CIMHYT, Hexico.

3. Maize Gera Plase Ieprovenent and Seed Production in NuFP,

Septeaber 1989. D.E.J. Stevens, FAO.

4. Production and harketing of Wheat Seed in Punjab. May 1988

P. Heisy Chaudry, CIMHYT.

5. Terainal Report. USAID/MART Project. Dr. Peter Hobbs.

6. The Agricultural Survey of Afghanistan. May 1988.

The Swedish Conaittee.

7. Report of the theat Travelling Seninar, 1987.

PARC/CIMMYT Wheat Paper B7-8.

8. Report of Trip to Afghanistan May 1987. CIMHYT Wheat Paper.

H. Braun B. Sheraand. CInkyt May 1987.

9. CIMHYT Horld theat Facts Trends, 1985.

10. Seed Technology Acquisition, Seed Industry Contact and On-Far

Manageaent in the Irrigated Punjab "Faraer" Behavior and

Perception 1987. ParC/CInMyt Paper No. 85.

11. Monitoring Wheat Varietal Diffusion in the Irrigated Punjab;

Results fros 1987-88 Brief:

12. Rehabilitation of Afghanistan Agriculture, Ionediate Steps.

Dr. Ray Fort, FAO REp., Islanabad.

13. Afghan Food Security Prograns.

Head Dr.: R. Arestrong/Andy Rude. USAID Dctober 88.

14. Agriculture Input Mobilization for Afghanistan Cheanics

Consulting Division Oct. 1988. 
1. Office of AID/REP and staff

2. Dr. Aza@ Gul

3. Dr. Abdul Makil

4. Mr. Al Mehoda

5. Dr. E. John Stevens

b. Dr. Ray fort

7. Dr. Bob Arastrong

8. Dr. Bill C. Wright

9. Dr. Nain Hashni

10. Dr. Mohanad Aslaa

11. Mr. Abuddin Khan

12. Dr. Saleea Khan

13. H. Ali Haider

14. Mr. Khaista 6ul

15. Dr. Shaloz Ahnad

16. Dr. Marren E. Kronstad

17. Dr. Jis Peterson

18. Dr. Frank Hertons

19. Dr. Derek Byerlee

20. Dr. Jia Longaeyer

21. Dr. S. Rajaraa

22. Dr. H. Braun
Swedish Conaission, Peshamar VITA, Peshanar

O/AID/REP, PEshamar

FAO, Islanabad

FAO, Isl amabad

TDY, O/AID/REP. Isl anabad

Minrock International, Islaaabad

PARC Wheat Coordinator, Islanabad

PARC Wheat Pathology

CCRI Director, Nowshera

CCRI Staff, Nowshera

Wheat Breeder, Nowshera

Wheat Breeder, Nonshera

NARC Agrononist, Islanabad

OSU, Corvallis, Oregon, USA

Nebraska U., Lincoln, Nebraska

USDA-ARS, Washington, D.C.

CIMHYT, Mexico

CIMNYT, Islanabad

CIMnyt, Wheat Breeder, Mexico

CIMHYT, Wheat Breeder, Turkey 
23. Dr. D. E. Saari

24. Dr. 6. Vaughese

25. Dr. D. Winkeleann

26. Dr. J. Dubin

27. Dr. J. M. Prescott

28. Dr. A. Rehaan

29. Dr. Jack Hessler

30. Mr. Abdul Hanil Chaudry

31. Mr. Mahoud Hassan Chaudry

32. Mr. Ali Denirtas

33. Bill Brooks

34. Charles Jenkins

35. Milton Gertsch

36. Dr. Anir Mohanaad

37. Dr. Yousef Chaudry
CIMnyt, Wheat Pathology, Turkey

Cinmyt, Asso.survey theat Prog, Mex

CIMnyt, General Director, Mexico

Cingyt, Nepal

Dekel b Seed Company

Genl Mgr. Seeds, Cargill Pakistan

Seed, Lahore

Country Mgr, Cargill Pak Geed, LHR Director PSC

Dep Director PSC

Manager Pioneer Seeds, Lahore

Fertilizer, Chemonics Tean

Fertilizer, Chemonics -

Fertilizer, Chemonics -

Chairnan, PARC, Isl anabad

Menber Plant Science, PARC, Isl.

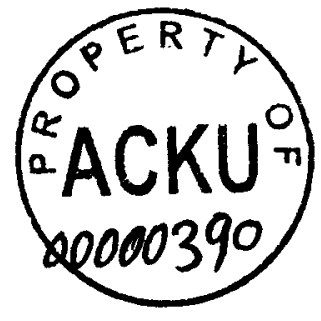

